\title{
Voter satisfaction and electoral systems: Does preferential voting in candidate-centred systems make a difference?
}

\author{
DAVID M. FARRELL ${ }^{1}$ \& IAN MCALLISTER ${ }^{2}$ \\ ${ }^{1}$ University of Manchester, $U K,{ }^{2}$ Australian National University, Canberra, Australia
}

\begin{abstract}
Over the years, many scholars have examined the relationship between electoral systems and measures of voter satisfaction with democracy. The tendency in these studies has been to explore the traditional Proportional Representation/non-ProportionalRepresentation dichotomy, assessing whether more proportional systems produce higher levels of satisfaction. This article examines another dimension of electoral system variation - namely the degree to which the ballot structure incorporates ordinal, or preferential features. Given that proponents of such systems extol their virtues as offering voters 'greater choice', it is interesting to explore how this actually plays with the voters. The article makes use of cross-national data from the comparative Study of Electoral Systems (CSES) project to examine the relationship between preferential voting and levels of satisfaction with democracy.
\end{abstract}

Since the onset of the current wave of democratization, there has been a growing interest in researching the institutional factors underlying citizen support for democracy. This has also, in part, reflected a renewed scholarly interest in seeking answers to the questions of whether and how institutions 'matter' (Weaver \& Rockman 1993) - in this instance, with regard to the theme of democratic stability. Of all the institutions that may matter, few would deny that electoral systems are among the most significant. They are the central institutional design issue for a new polity to resolve (e.g., Sartori 1997; Taagepera 2002), and they are also among the most malleable of the political institutions (Sartori 1968: 273). Certainly, when compared to the other fundamental institutional decisions of a polity (such as, e.g., deciding between presidentialism and parliamentarism), electoral systems are generally far easier to change because, on the whole, they tend not to be constitutionally embedded and are therefore more open to the whims of politicians (Bowler et al. 2003).

Electoral system design may be perceived as important by academic scholars and electoral engineers (Lijphart 1994; Reynolds 2002; Sartori 1997; Taagepera \& Shugart 1989), but what tangible evidence is there of an electoral system actually making a difference to democratic stability? Developments in large-scale cross-national surveys have facilitated research into this question, with much of it focused on Arend Lijphart's well-known framework 
distinguishing between majoritarian and consensual democracies (Lijphart 1999). Under this framework, the electoral system is treated as a core variable and is operationalized in terms of its vote-aggregation properties as more or less proportional. The basis of Lijphart's argument with regard to electoral systems is that proportional representation (PR) systems are better than non-proportional systems because they facilitate the representation of all relevant societal and ethnic groupings, and in the penultimate two chapters of his Patterns of Democracy (Lijphart 1999), he provides detailed supporting evidence of this. This has prompted others to examine the crossnational evidence, though in some cases with differing conclusions (Castles 1994; Rose 1992). Two prominent studies are by Anderson and Guillory (1997) and Norris (1999), both of which use cross-national survey data to test the role of proportional representation electoral systems in promoting citizen satisfaction with democracy. The Anderson and Guillory study, based on Eurobarometer data, finds clear evidence of a positive relationship between PR systems and measures of democratic satisfaction. By contrast, Norris's findings, using a far wider set of cases (based on World Values data), are more equivocal: if anything, 'majoritarian institutions tended to produce greater institutional confidence than consociational arrangements' (Norris 1999: 233; also Norris 2004).

Whether and how electoral systems can affect levels of voter satisfaction with democracy is therefore unresolved; work is required, among other things, on how best to operationalize the dependent variable (Linde \& Ekman 2003). In this article, we argue that the independent variable is also in need of more attention. The studies to date have treated electoral systems solely in terms of their vote-aggregation outcomes, with attention focused on representation in the microcosmic sense (McLean 1991) in terms of who gets elected and the representation of social and ethnic groups - in short, the age-old issue of 'proportionality'. It is universally accepted in the electoral systems literature that the two most important features of an electoral system affecting aggregate proportionality are district magnitude (the number of politicians elected in a district) and electoral formula (the counting rule determining how votes are translated into seats) (e.g., Farrell 2001; Katz 1997b; Lijphart 1994; Rae 1967). Yet there is a third feature of electoral systems: ballot structure; and while its effects on proportionality are negligible (Lijphart 1994), there is no disputing that it has an effect both on voters, in the sense of determining the nature and extent of choice available to them on polling day, and on politicians, who are cognizant of the effect on voters and react accordingly.

In this article, we use the Comparative Study of Electoral Systems (CSES) survey data to assess whether ballot structure has a wider impact on levels of 
voter satisfaction with democracy. We start, in the first section, with a discussion of the ballot structure dimension of electoral systems, how it might be operationalized and what affects we might expect it to have on voter attitudes to politics. The second section uses two waves of data from the Comparative Study of Electoral Systems (CSES) to assess the role of ballot structure, as well as a battery of other electoral system and individual-level variables, in influencing voter satisfaction with democracy in 29 countries. The third and fourth sections take a further look at the evidence by examining the potential indirect relationships between our electoral systems variables and measures of satisfaction with democracy. The fifth section concludes.

\section{Ballot structure and democracy}

From Douglas Rae (1967) onwards, the main distinction in electoral system ballot structures is between categorical and ordinal systems, the latter allowing voters greater choice in determining the fate of individual candidates. At one extreme are non-preferential systems, such as closed list, in which the voter makes a simple categorical choice between parties. At the other extreme are preferential systems, such as the single transferable vote (STV) system, in which the voter can rank order all the candidates (from all parties) on a ballot paper. There is a range of preferential systems that vary in terms of the degree of choice given to voters. Other prominent members of this category include: the cumulative vote, the limited vote, open list, panachage and the alternative vote (AV; also referred to as 'preferential voting', or 'instant run-off voting') (Bowler et al. 2002; Bowler \& Grofman 2000; Grofman et al. 1999). These systems share in common the characteristic that the voters are given much greater freedom in completing the ballot paper, either in terms of making multiple marks against several candidates, or in some cases being able to rank-order the candidates.

There can be little doubt that this feature of voter choice has important implications for how voters cast their ballot (not least on the degree of effort those bothering to vote are required to make in the polling station), how parties and candidates campaign, and how politicians represent their voters (e.g., Ames 1995; Bowler 1986; Bowler \& Farrell 1993; Cox 1990; Katz 1980; Shugart 2001). It is easy to see how this might have an impact on the attitudes of voters to the political system. The connection between ballot structure characteristics of electoral systems and voter attitudes to democracy derives from at least three mechanisms, one originating directly from the voting act itself, another based more indirectly on the relationship between politicians and their voters, and a third referring to the ideological tendency within 
the party political system. In the first instance there is the argument usually propounded by supporters of preferential systems like STV that a principal strength is the maximization of voter choice (e.g., Hallett 1984: 119-120; Lakeman 1974: 111). Even among more sober scholarly treatments, there is stress on how systems like STV give 'voters greater choice and makes possible ballot splitting to express highly differentiated preferences' (Bowler \& Grofman 2000: 1). In a context in which voters are being given more choice in the electoral act, it could be argued that this should result in a greater sense of efficacy on the part of voters and more say in electing their representatives.

Following on from this, a second perspective draws attention to the linkage between politicians and voters (Lawson 1980; Mitchell 2000; Römmele et al. 2005). There is general agreement that ballot structure affects the representative role of politicians (e.g., Ames 1995; Carey \& Shugart 1995; Shugart 2001), and studies based on surveys of politicians have demonstrated how electoral systems that are characterized by a candidate-orientation in politics and high degrees of preferential voting tend to produce greater attention to personal vote chasing by politicians and the maintenance of close links with their electorates (Bowler \& Farrell 1993; Farrell \& Scully 2003; though see Katz 1997a). There are grounds for expecting a more positive attitude by voters towards their elected representatives in such systems (and by extension towards the wider political system) than might be the case in those electoral contexts in which politicians are devoting most attention to their internal selectorates.

Finally, there is the issue of how preferential systems might impact on party politics more generally, in which a distinction can be drawn between centrifugal and centripetal tendencies (Cox 1990; Sartori 1976). The basic idea is that preferential electoral systems encourage a politics of accommodation between politicians (Horowitz 1991; Reilly 2001; Sisk 1995). Unlike Lijphart's consensual framework stress on the need for strong, cohesive parties supported by closed list PR in which the party elites can forge alliances across party lines and promote a top-down politics of accommodation, this alternative perspective adopts a bottom-up approach in which the electoral incentives promoted by preferential electoral systems encourage politicians to move towards the centre ground in an effort to sweep up more support in the form of vote preferences (see also Reynolds (1999), on STV). The implication of this argument is that such tactics, if successful, should help nurture democratic stability - and therefore should be manifest in higher levels of voter support for democracy. This last mechanism - regarding the possible centripetal tendencies of preferential systems - suggests a significant role for these systems in newer democracies, in helping them to consolidate. 


\section{Preferential voting and candidate-centredness}

When the focus is on ballot structure, electoral systems can be differentiated in terms of the nature of the vote choice (i.e., party-based versus candidate-based votes) and also the extent of the vote choice in terms of degrees of ordinality, or preferential voting (Farrell 2001). Systems characterized by candidatebased voting and high degrees of ordinality (which we shall refer to hereinafter as 'preferential' systems) encourage a greater emphasis by candidates on cultivating personal votes as opposed to party-centred electoral systems where the fate of the candidate is determined largely by the support for their parties. ${ }^{1}$ Following the lead of Matthew Shugart (2001; which in turn builds on his earlier work - see Carey and Shugart 1995), we develop an index of 'intraparty efficiency' that taps the preferential/non-preferential distinction in electoral systems.

Like Shugart, we operationalize variations in our sample electoral systems based on three main characteristics that he terms 'Ballot', 'Vote' and 'District', in which the higher scores across these components are indicative of a candidate-centred preferential system and lower scores of a party-centred categorical system. We have adapted Shugart's original schema in part because our focus is on a wider range of electoral systems than dealt with in his paper (furthermore, unlike him, our focus is less exclusively on testing the overall 'efficiency' of the mixed-member electoral systems), in part also reflecting limitations in our access to full and complete data on all the cases covered by the CSES data set, and finally because of disagreements with some of his categorizations (as outlined below).

The Ballot component is designed to measure the degree of party versus voter control over the ballot placement of candidates, revealing the extent to which the party leadership (and/or selectorate) can exercise influence over the party's candidates. The lower the ballot control, the greater the incentive for candidates to place emphasis on their personal reputation. Our coding, which differs from Shugart's only in the sense that we do not include details on candidate selection rules, ${ }^{2}$ is as follows:

1. Voters may not disturb the order of the candidate list (closed list PR). ${ }^{3}$

2. Voters may disturb the order of the candidate list (open list PR).

3. Ballot access requires first surviving a preliminary round of popular voting (the French runoff system).

4. Ballot access nearly unrestricted (STV).

Shugart's Vote component distinguishes between systems that require voters to vote for lists or candidates (a nominal vote). Our coding of this 
component also differs from Shugart's, but in this instance it is because we disagree with some of his underlying assumptions. In order to understand the basis for our disagreement, we first need to provide some background on how Shugart arrived at his codes. The Shugart codes build on an earlier paper (Carey \& Shugart 1995) that entailed a merger of what were two distinct components: Pool $_{1}$ and Votes $_{1}{ }^{4}$

The first component, $\mathrm{Pool}_{1}$, was designed to measure the extent to which votes cast for one candidate also contributed to the number of seats a party wins in the district in which the greater the extent of pooling the lower the incentive for candidates to cultivate personal votes. On one extreme are electoral systems that have no pooling, so that a candidate's fate is determined solely by his or her personal vote-chasing activities. Carey and Shugart view Japan's (now-defunct) SNTV system and electoral systems that incorporate candidate primaries as good examples of this. AV and STV are categorized as an intermediate category 'where voters can designate to whom their votes should be transferred if they are not needed to elect their first choice, or if their first choice is too unpopular to be elected' (Carey \& Shugart 1995: 422), whereas the list systems, regardless of their variation in terms of degrees of ordinality, are subsumed under the one category of 'pooling across whole party' and are placed on the opposite extreme to SNTV. Carey and Shugart's placement of AV and especially of STV is problematic and certainly is at odds with the usual conceptualization of these systems as promoting candidatecentred electoral politics (for discussion, see Marsh 2000; Katz 1980). It may well be true that voters 'can designate' how their votes will transfer, but what has to be recognized is that the candidates (in varying degrees of desperation) are seeking to influence the nature of that designation. The result is a high degree of candidate-centred politics. For that reason, we find it hard to support the contention that the application of the Pool $_{1}$ component should result in STV being ranked at a midpoint on a scale of party-centred versus candidatecentred politics.

The Votes ${ }_{1}$ component, as outlined by Carey and Shugart (1995), distinguishes between single-vote list and nominal systems, with systems of 'multiple votes' (i.e., ordinal systems) comprising an intermediate category. According to Carey and Shugart (1995: 422), 'the value to legislative candidates of personal reputation' is highest in nominal systems. They provide very little indication of how they might distinguish the different multi-candidate systems, but the following extract is revealing:

[W]hen multiple votes are cast, personal reputation is not as overwhelmingly important relative to party reputation as when all candidates are competing simultaneously for the same indivisible support of each voter. 
When multiple votes are cast simultaneously, the candidates from one party can run as a bloc, rather than running against each other. (Carey \& Shugart 1995: 422)

Again, this appears to underestimate the degree of intra-party candidatecentred campaigning that often occurs in preferential elections such as STV in Ireland (in some instances this takes the form of full-scale personal battles between candidates of the same party; see, e.g., Farrell 1985).

In his more recent paper, Shugart (2001) merges the Pool ${ }_{1}$ and Votes ${ }_{1}$ components, and his new Vote component comprises the following ranking:

1. Vote for list only (closed list).

2. Vote list or nominal, but list votes predominate (ordered list).

3. Vote is nominal only, but vote may pool or transfer to other candidates (STV).

4. Vote is nominal or list, but nominal votes predominate and pool to other candidates (open list).

5. Vote is nominal only and non-transferable (single member plurality, or SMP).

Clearly there is no disagreeing with the view that a closed list system lies at one extreme on this component with ordered list systems lying in an intermediate position. For the reasons set out above, our biggest area of difference relates to those systems in which the vote is nominal only and non-transferable (i.e., the single member plurality systems in which the vote is a simple categorical choice between candidates). While this is likely to promote greater degrees of candidate-centred politics than closed list systems because candidates are striving for personal votes in their district, it is inconceivable that this would result in higher levels of personal vote chasing than systems where the vote is nominal only with the vote pooling or transferring to other candidates (i.e., STV). ${ }^{5} \mathrm{We}$ also contend that STV systems promote personal vote chasing to a higher degree than open list systems (where the vote is nominal or list, but nominal votes predominate and pool to other candidates). As a consequence, our Vote component is coded as follows:

1. Vote for list only (closed list).

2. Vote list or nominal, but list votes predominate (ordered list).

3. Vote is nominal only and non-transferable (SMP).

4. Vote is nominal or list, but nominal votes predominate and pool to other candidates (open list). 
5. Vote is nominal only, but vote may pool or transfer to other candidates (STV).

In the case of the District component our coding is identical to Shugart's. This component takes account of an earlier argument developed by Carey and Shugart (1995) about how the effect of district magnitude $(M)$ can vary depending on the nature of the ballot structure. In systems where voters cast party-based votes, they find that the personal reputation of the candidate declines in significance as $M$ rises, whereas in systems characterized by candidate-based (nominal) votes, as $M$ rises and candidates face more interparty and intra-party competitors, the incentives for personal vote chasing increases. ${ }^{6}$ This component is coded as follows:

1. $M>1$, with Vote $=1$

2. $M=1$

3. $M>1$, with Vote $>1$ and Ballot $>1$.

Using this coding scheme, we can locate our 29 countries $^{7}$ on a scale from predominantly candidate-centredness to predominantly party-centredness; the results of this exercise are shown in the first part of Appendix Table 1. For now, taking all except the mixed-member (MM) systems into account, this produces seven different grades. The scores on our index do not carry any numerical value; the index is simply based on the two logical extremes, taking account of the seven intervals. The resulting index values are reported in the first column of Table 1.

Following Shugart's lead, a separate set of assumptions apply with regard to MM systems. These mix nominal and list voting elements. Since research demonstrates that they tend on the whole to place the greater emphasis on the particularistic features of SMP systems (in terms of the legislative role of MPs) than on closed list systems (Shugart \& Wattenberg 2001), we need to produce an index rating that places them somewhat closer to the former. In order to do this, for those MM systems that use plurality rules for the nominal vote element (in the single seat districts (or SSDs) these include Germany, Japan, Korea, Mexico, New Zealand and Taiwan), we first take the mean of 4.3 (SSD-plurality score) and 1.4 (closed list score), which is 2.9. Then, to reflect the bias in favour of SSDs, we take the mean of 2.9 and 4.3 (SSD-plurality score), producing a score of 3.6. In the case of those MM systems that use runoff rules for the nominal vote element (Hungary and Lithuania), the means are based on the SSD two-round systems rather than on the SSD-plurality systems, thus producing a score of 4.7 . 


\section{Preferential systems and voter satisfaction with democracy}

With the proliferation of democracy across the world following the collapse of communism, much scholarly attention has been devoted to studying citizens' satisfaction with democracy. Starting with Easton (1965) and Lipset (1966), scholars have made a distinction between satisfaction with the day-to-day operation of a government and the diffuse support for values, norms and belief that underpin the political system. More recently, Norris (1999) has identified five objects of support (for the political community, the principles, the performance and the institutions of the regime, and for political actors) and shown that citizens clearly differentiate between each of them. Others have found similar results (see, e.g., Karp et al. 2003; Thomassen \& van der Kolk, forthcoming), though critics have questioned both the concept and meaning of the measures used (Cannache et al. 2001).

The CSES dataset allows us to examine overall citizen satisfaction with democracy in their country. The question was: 'On the whole, are you very

Table 1. Scoring electoral systems on the intra-party dimension

\begin{tabular}{clll}
\hline Index & Component scores & Description of system & \multicolumn{1}{c}{ Cases } \\
\hline 10.0 & $4,5,3$ & STV & Ireland \\
8.6 & $4,5,2$ & AV & Australia \\
7.1 & $2,4,3$ & Open list, panachage & Denmark, Switzerland \\
5.7 & $3,3,2$ & SSD, two rounds & France, United States \\
4.7 & {$[$ MM fix A $]$} & MMS with runoff rule & Hungary, Lithuania \\
4.3 & $1,3,2$ & SSD-plurality with & Canada, United Kingdom \\
& & party control & \\
3.6 & {$[$ MM fix B] } & MMS with plurality & Germany, Japan, Korea, \\
& & rule & Mexico, New Zealand, \\
& & Taiwan \\
2.9 & $2,2,1$ & Ordered list & Belgium, Czech Republic, \\
& & & Netherlands, Poland, \\
& & Slovenia, Sweden \\
1.4 & $1,1,1$ & Closed list & Bulgaria, Iceland, Israel, \\
& & & Norway, Portugal, Romania, \\
& & & Spain
\end{tabular}

Notes: The rankings range from most candidate-centred to most party-centred electoral systems. For details on the coding, see text and Appendix Table 1. MM fix A: For MM systems with runoff rules in the SSDs. Mean of 5.7 (SSD two round score) and 1.4 (closed list score $)=3.6$. Mean of 3.6 and 5.7 (SSD two round score) $=4.7$. MM fix B: For MM systems with plurality rules in the SSDs. Mean of 4.3 (SSD plurality score) and 1.4 (closed list score $)=2.9$. Mean of 2.9 and 4.3 (SSD plurality score $)=3.6$. 
satisfied, fairly satisfied, not very satisfied, or not at all satisfied with the way democracy works in [country]?' The great advantage of the CSES is that it permits us to examine a wider range of countries than is usually available in similar comparative surveys; the main disadvantage is that because of the nature of the data collection, topics cannot be covered in great depth. We are therefore unable to differentiate satisfaction with democracy into the component parts identified by other researchers. Nevertheless, as Table 2 shows, we are able to show the wide variation in satisfaction with democracy that exists across the 29 countries included in our analysis, ranging from Norway at the top to Bulgaria at the bottom.

In general, as we would expect and has been found in other research (Norris 1999; Karp et al. 2003), it is the older established democracies that display higher levels of voter satisfaction compared to the newer democracies. For example, of the seven countries with the lowest levels of satisfaction, all but two are former communist states, and of the other two, Portugal was a dictatorship until 1975 and Korea has experienced endemic problems of political stability. It is perhaps worthy of note, however, that with the exception of Bulgaria, very few respondents reply 'not at all satisfied' to the question, and in most countries, the figure is less than one in 10. Indeed, of the 29 countries, there are only six in which the proportions of people saying they are 'not very' or 'not at all' satisfied outnumber those who say 'very' or 'fairly' satisfied.

To examine the relationship between satisfaction with democracy and their placement on our intra-party measure, we construct a single measure of satisfaction scored from a low of zero to a high of 10 (see Table 3). The correlation between the two variables is 0.33 , showing that the higher the candidatecentredness of the electoral system, the higher the level of popular democratic satisfaction. This, of course, is based on the 29 countries each treated as a single unit of observation. However, voter satisfaction is a consequence of a wide range of individual circumstances in addition to systematic characteristics and all must be taken into account in order to test the robustness of the relationship. In order to control for these potentially confounding characteristics, we rely on the individual level CSES data, which includes over 40,000 observations across the 29 countries. The results are estimated for those who reported voting in the previous national election. ${ }^{8}$

In addition to our intra-party variable, the other independent variables are of two types. First, there are the characteristics of individual voters ranging from gender, age and marital status to education, employment characteristics and income. ${ }^{9}$ Following the lead of the studies discussed above (Anderson \& Guillory 1997; Lijphart 1999; Norris 1999), the other characteristics of the electoral system that we take account of in our multivariate model include the following (see the second half of Appendix Table 1). Disproportionality is 


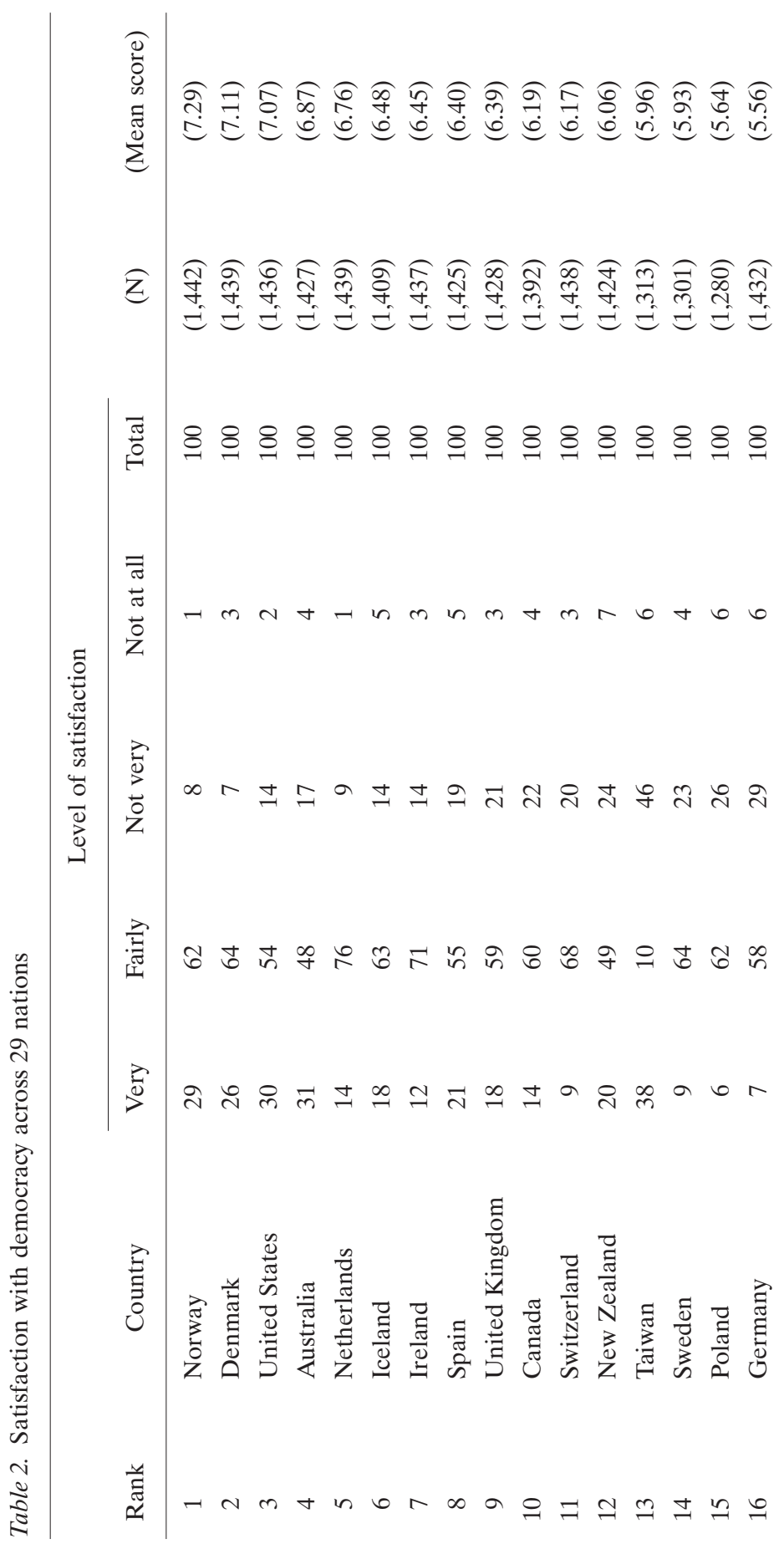




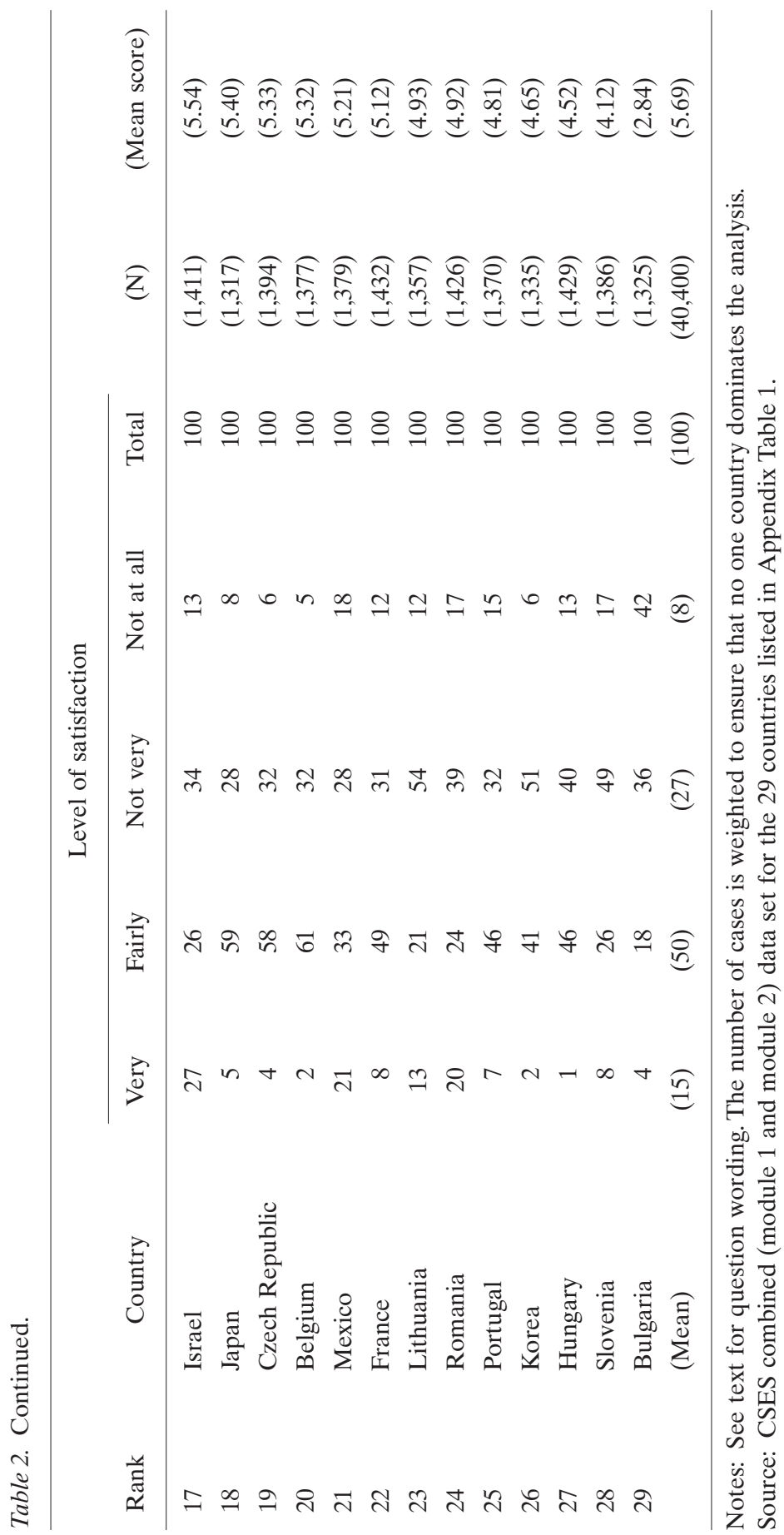


measured by the Gallagher index, ${ }^{10}$ with the higher the figure the greater the disproportionality produced by the electoral system. Assembly size is also included and we should expect greater proportionality where the size is larger, although this could be countered by higher levels of disproportionality (Lijphart 1994). Finally, the average voting age population per MP measures the proximity of the voter to the elected representative, and we would hypothesize that smaller ratios of voters to MPs would increase voter satisfaction (Carey \& Shugart 1995) since elected representatives would be more visible and more accessible to their electors. ${ }^{11}$

In order to estimate the net contribution of the intra-party dimension to voter satisfaction, we provide four regression models (Table 4). ${ }^{12}$ The first model includes just one independent variable (the intra-party dimension) and the standardized coefficient therefore represents the correlation between the two items. The second equation includes the measures of voter characteristics. In this model, while the intra-party dimension is very slightly reduced in magnitude, it remains the strongest predictor in the equation; other variables of note are the importance of family income and unemployment, with more

Table 3. Variables, scoring and means

\begin{tabular}{|c|c|c|c|}
\hline Variable & Scoring & Mean & St Dev \\
\hline \multicolumn{4}{|l|}{ Dependent variable } \\
\hline Satisfaction with democracy & $\begin{array}{l}0=\text { very unsatisfied } \\
3.3=\text { unsatisfied, } 6.7=\text { satisfied, } \\
10=\text { very satisfied }\end{array}$ & 5.69 & 2.74 \\
\hline \multicolumn{4}{|l|}{ Voter characteristics } \\
\hline Age & Years & 46.46 & 16.45 \\
\hline Gender & $1=$ male, $0=$ female & 0.49 & 0.50 \\
\hline Tertiary education & $1=$ yes, $0=$ no & 0.21 & 0.40 \\
\hline Unemployed & $1=$ yes, $0=$ no & 0.05 & 0.22 \\
\hline Family income & Quintiles & 2.99 & 1.38 \\
\hline \multicolumn{4}{|l|}{ Other electoral system characteristics } \\
\hline Intra-party index & From a low of 0 to a high of 10 & 3.83 & 2.18 \\
\hline Disproportionality & $\begin{array}{l}\text { From a low of } 1.49 \text { to a high of } \\
21.37\end{array}$ & 6.39 & 4.62 \\
\hline Assembly size & Number in hundreds & 2.93 & 1.66 \\
\hline Voting age population per MP & Number in thousands & 67.98 & 80.61 \\
\hline \multicolumn{4}{|l|}{ Country characteristics } \\
\hline Democratic experience & Years since universal franchise & 52.00 & 33.20 \\
\hline GDP per capita & Thousand US\$ & 17.91 & 8.45 \\
\hline
\end{tabular}

Sources: As for Table 2. 


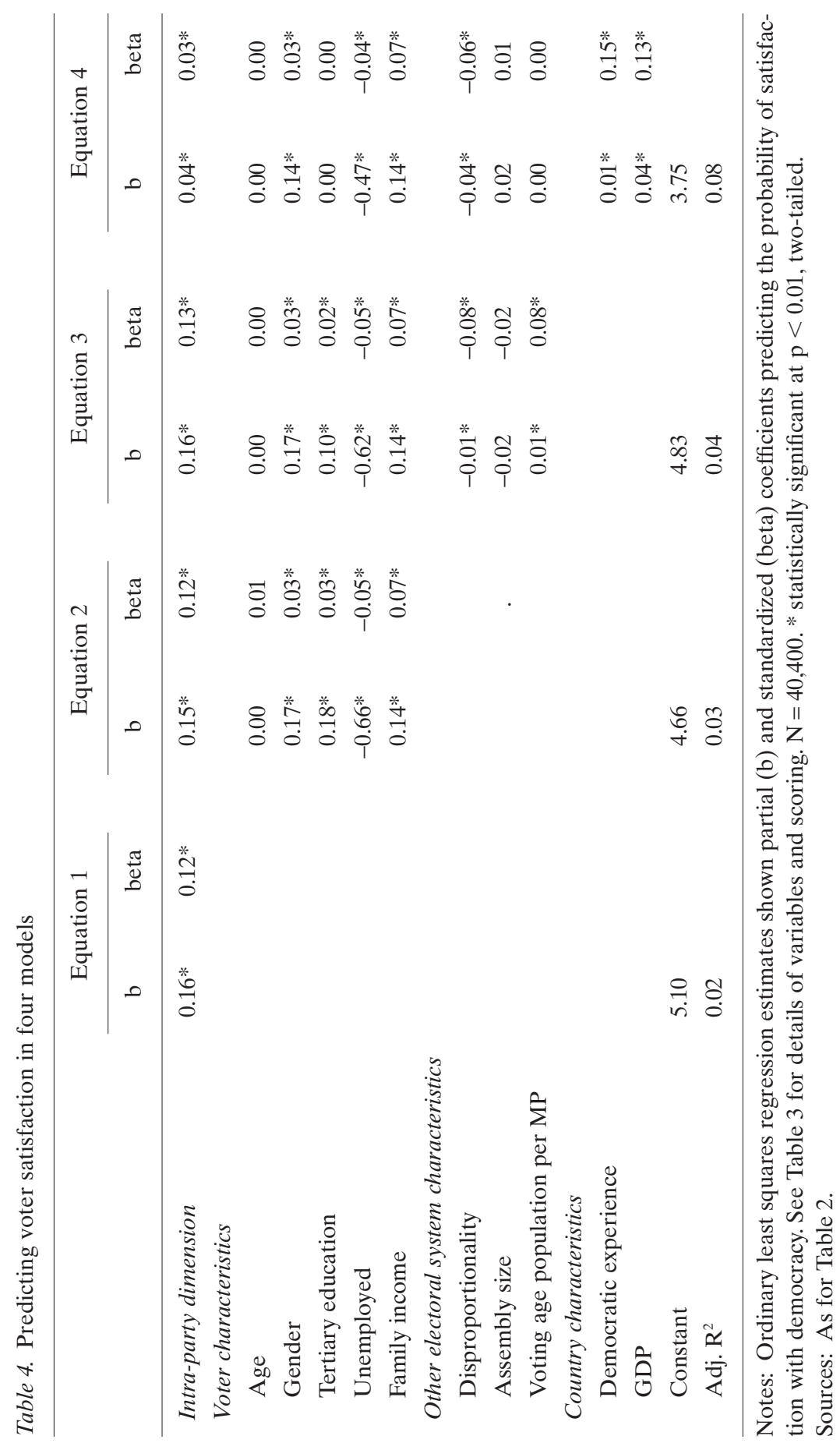


affluent respondents being more satisfied than their less affluent counterparts, net of other things. Net of a wide range of individual characteristics, then, the intra-party measure remains an important predictor of the degree of voter satisfaction with the democratic process in the particular country.

The intra-party variable maintains its predictive strength when we introduce the three additional electoral system characteristics into the equation. Two of the three measures are important (assembly size just fails to reach statistical significance) and this is broadly consistent with the studies cited above (Anderson \& Guillory 1997; Lijphart 1999). The fourth equation shows that much of the importance of the intra-party dimension is attributable to country characteristics; here measured by the length of the democratic experience and GDP. Although the intra-party dimension remains statistically significant, the coefficient drops from 0.16 to 0.04 , suggesting that much of its impact in shaping democratic satisfaction is a consequence of the accumulated democratic experience and economic development of the country in question. ${ }^{13}$

\section{Electoral systems and political attitudes}

So far we have viewed electoral systems as having a direct effect on satisfaction with democracy, and the results in the previous section have shown that there is strong empirical support for this proposition, net of a range of other factors. A further possibility, which we test in this section, is that electoral systems (as conceptualized by our main intra-party variable, and also by the more conventional features of aggregate disproportionality, assembly size and the ratio of MPs per voting age population (VAP)) also have indirect effects on satisfaction with democracy via the more general political views that citizens form about how the system operates and how effective it is. ${ }^{14}$ The analysis in this section provides a sterner test of our intra-party variable, as well as of the other electoral system variables, because on this occasion we are looking for evidence of the actual 'mechanisms' of linkage between the electoral system feature and the levels of voter satisfaction with democracy.

In a previous section we outlined three such mechanisms relating specifically to our intra-party variable. The first mechanism was a sense of voter efficacy deriving directly from the voting act itself so that voters in preferential systems felt greater empowerment over the political system compared to voters in other electoral systems. The second was the degree of linkage between politicians and voters so that voters in preferential systems had easier access to their elected representatives. And third was ideological tendency within the party political system. In large part, the first of these 
mechanisms formed the basis of the analysis in the previous section, which examined the direct relationship between the nature of the electoral system and the attitudes of voters towards the political system. The remaining two mechanisms suggest a more indirect relationship with, in turn, politicians and parties playing key mediating roles. Given the focus of our other electoral system variables (particularly disproportionality and assembly size) on the aggregate proportionality of the election result, we should add a fourth mechanism of linkage - namely the degree to which the election result is perceived as fair.

Taking our (remaining) three mechanisms together, therefore, we have the basis for an examination of how electoral systems link with voter attitudes to democracy. In the first instance, there are voter attitudes to the role of political parties. We would expect that the more open the system is to minor parties and independents, the greater the support for parties as an organizing element within the political system. Conversely, we might expect a negative relationship between our intra-party variable and parties, reflecting a greater emphasis on candidate-centred voting. Second, the extent to which voters believe that their elected representatives were responsive to and knowledgeable about their needs should be related to smaller assembly sizes, the lower ratios of elected representatives to electors and the nature of the ballot structure. Third, we would expect that the perceived fairness of the electoral system would be a consequence of disproportionality and possibly also the assembly size. In this case, we might expect that more proportional systems will be associated with greater support for the view that the election was fair. The perceived fairness could also be related to ballot structures in the sense that voters in candidate-centred systems might feel a greater sense of 'ownership' over the electoral process due to their determination of the fate of individual candidates. ${ }^{15}$

Questions measuring these three dimensions were asked in the first CSES module and are shown in Table 5. Unfortunately, the questions were not asked in the second CSES module and for that reason the results presented in Tables 5 and 6 are based on 26 countries, excluding Bulgaria, France and Ireland, which were only surveyed in module 2 . In most countries, political parties are regarded as necessary in order to make the system work; almost half of the respondents in Table 5 support this proposition, and just under one in 10 hold the opposing view. Similarly, just over half see the last election in their country as having been conducted fairly; once again just under one in 10 of the respondents take a negative view. Opinions are more evenly balanced on whether or not elected representatives know what ordinary voters think; while about one-third take a neutral view, 40 per cent believe that they are not in touch compared to 28 per cent who believe they are. 
These attitudes are related to the objective aspects of the electoral system in the models outlined in Table 6. The intra-party dimension is significant in shaping attitudes in two out of the three cases: voters in more candidatecentred systems are more likely to believe that elections have been conducted fairly and, counter-intuitively, to consider that elected representatives are less likely to know what ordinary people think. In each case, these findings are net of a wide range of other factors including voter, electoral system and country characteristics. The other three electoral system characteristics are also consistently important. The greater the disproportionality of the system, the more negative the voters' views of how the system operates - as we would expect. Indeed, in the case of how fair elections are perceived to be, the disproportionality of the system is the important variable in the equation. Larger assemblies also promote more positive views, as do smaller district sizes - again as we would expect.

It remains to test the hypothesis that the intra-party dimension increases favourable attitudes towards democracy, net of a wide range of other factors including the attitudes that voters hold about the political system itself. This hypothesis is tested in Table 7, which presents the results of a regression analysis, predicting satisfaction with democracy from a wide range of other characteristics. The results show that the intra-party dimension does indeed remain a consistent predictor of satisfaction, net of individual and system-level characteristics. While the total effect is not large, it remains statistically significant and is similar in magnitude to disproportonality and assembly size, or to any of the individual characteristics of voters. The most important electoral system predictor of satisfaction is district size. Among the other variables, attitudes to the electoral system are consistently important and the belief that elections are conducted fairly is easily the most important predictor in the

Table 5. Attitudes toward the political system

\begin{tabular}{lrlrlr}
\hline $\begin{array}{c}\text { Political parties } \\
\text { necessary? }\end{array}$ & \multicolumn{4}{c}{$\begin{array}{c}\text { Elections conducted } \\
\text { fairly? }\end{array}$} & \multicolumn{2}{c}{$\begin{array}{c}\text { MPs know what } \\
\text { people think? }\end{array}$} \\
\hline 1. Necessary & 49 & 1. Fair & 56 & 1. Know & 9 \\
2. & 26 & 2. & 22 & 2. & 19 \\
3. & 16 & 3. & 13 & 3. & 32 \\
4. & 5 & 4. & 5 & 4. & 22 \\
5. Not necessary & 4 & 5. Unfair & 4 & 5. Don't know & 18 \\
Total & 100 & & 100 & & 100 \\
(N) & $(35,107)$ & & $(32,063)$ & & $(35,198)$ \\
\hline
\end{tabular}

Notes: For detailed question wordings, see text.

Source: CSES module 1. 


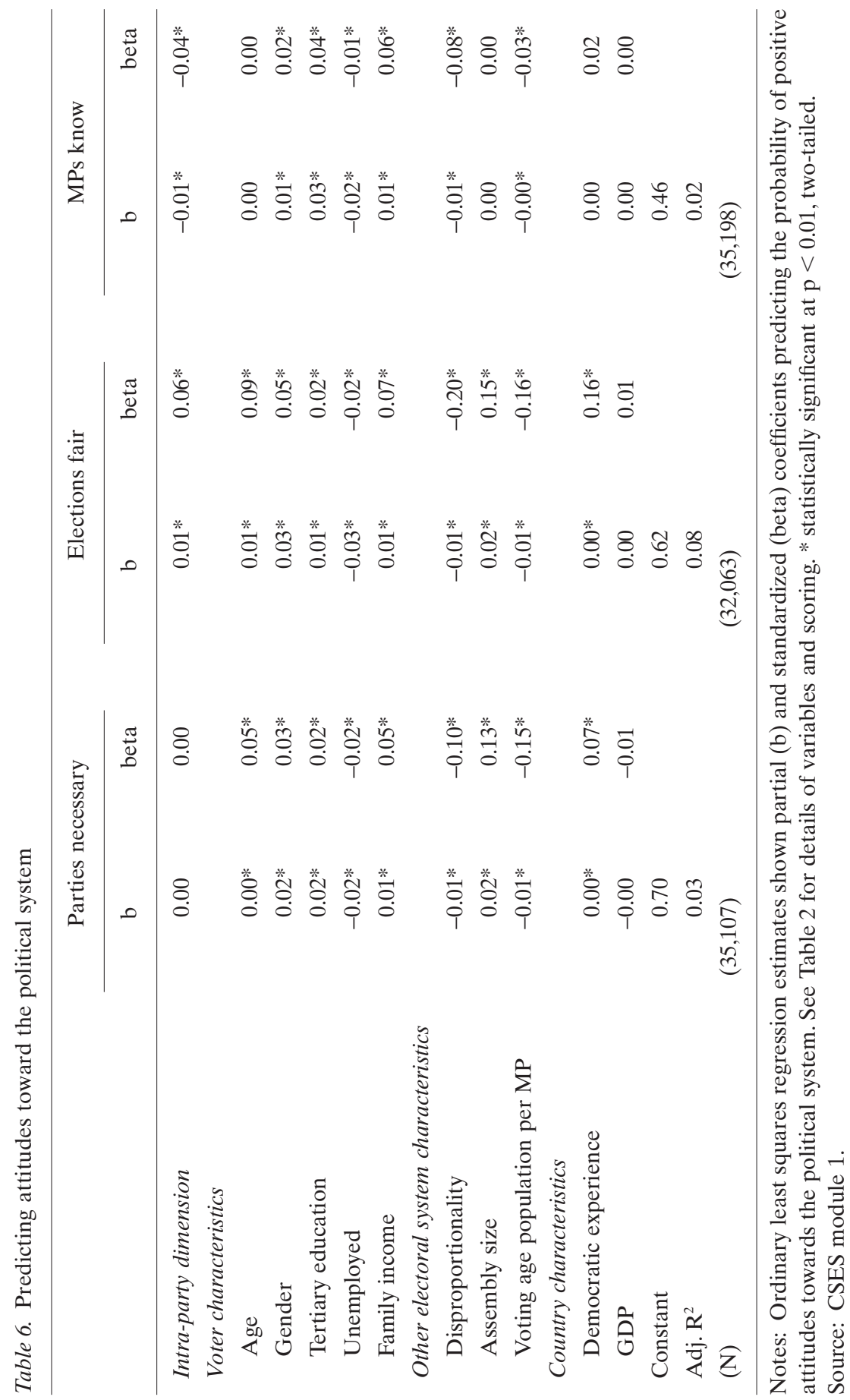


equation. Second in importance is the length of democratic experience, followed by believing that MPs know what people think and taking the view that political parties are necessary in making democracy work.

Overall, then, the analysis presented in Table 7 provides additional support for the argument that electoral systems do indeed affect levels of voter satisfaction with democracy, and in this instance we have evidence of the nature of the linkage between these two sets of variables. The results in Table 6 show

Table 7. Democratic satisfaction, attitudes toward the political system and electoral system characteristics

\begin{tabular}{|c|c|c|}
\hline & \multicolumn{2}{|c|}{$\begin{array}{l}\text { Democratic } \\
\text { satisfaction }\end{array}$} \\
\hline & $\mathrm{b}$ & beta \\
\hline Intra-party dimension & $0.04 *$ & $0.03^{*}$ \\
\hline \multicolumn{3}{|l|}{ Attitudes to the electoral system } \\
\hline Parties are necessary & $1.13 *$ & $0.11^{*}$ \\
\hline Elections conducted fairly & $2.10 *$ & $0.22 *$ \\
\hline MPs know what voters think & $1.06^{*}$ & $0.12^{*}$ \\
\hline \multicolumn{3}{|l|}{ Voter characteristics } \\
\hline Age & $-0.00 *$ & $-0.02 *$ \\
\hline Gender & $0.09 *$ & $0.02 *$ \\
\hline Tertiary education & -0.08 & -0.01 \\
\hline Unemployed & -0.28 & -0.02 \\
\hline Family income & $0.07 *$ & $0.04 *$ \\
\hline \multicolumn{3}{|l|}{ Other electoral system characteristics } \\
\hline Disproportionality & $0.02 *$ & $0.03^{*}$ \\
\hline Assembly size & $-0.07 *$ & $-0.04 *$ \\
\hline Voting age population per MP & $0.01 *$ & $0.09^{*}$ \\
\hline \multicolumn{3}{|l|}{ Country characteristics } \\
\hline Democratic experience & $0.01 *$ & $0.15^{*}$ \\
\hline GDP & -0.01 & -0.02 \\
\hline Constant & 1.95 & \\
\hline Adj. $\mathrm{R}^{2}$ & 0.15 & \\
\hline$(\mathrm{N})$ & $(35,105)$ & \\
\hline
\end{tabular}

Notes: Ordinary least squares regression estimates shown partial (b) and standardized (beta) coefficients predicting the probability of satisfaction with democracy. See Table 2 for details of variables and scoring. * statistically significant at $\mathrm{p}<0.01$, two-tailed.

Source: CSES module 1. 
that the intra-party nature of the electoral system has an impact on popular perceptions of electoral fairness and via that to satisfaction with democracy (as well as having a direct effect in its own right). While this analysis provides further support for the argument that the 'macro' measure of systemic proportionality is the most important electoral system feature, there are also grounds for arguing that the 'micro' aspects of electoral systems (in this case, the intra-party dimension affected particularly by the ballot structure) have a role to play and our analysis in Table 7 shows that this role is far from being insignificant.

\section{Conclusion}

With the mushrooming of new democracies over the past few decades, electoral engineering has become big business. On an ever-increasing basis, political scientists are invited to comment on the design of new electoral systems; indeed, this has also included consideration of fundamental reform of electoral systems in established democracies (Italy, Japan, New Zealand, Israel, the United Kingdom, Canada, etc.). While few today would demur from Richard Katz's (1997b: 308) contention that the answer to the question which electoral system is 'best' depends on 'who you are, where you are, and where you want to go', this has not deterred specialists from proffering advice on where to place greatest emphasis in electoral system design (for a recent illustration, see Taagepera 2002). Among the items that seem to feature in these deliberations, two seem most prominent: the level of overall proportionality of the system, and the nature and degree of linkage between politicians and voters. Certainly, this is seen, by at least some scholars, as a major factor behind the recent fashion for mixed systems, whose principal virtue is apparently that they represent 'the best of both worlds' in terms of these two characteristics (Shugart \& Wattenberg 2001).

Our analyses started from a similar interest in promoting the joint virtues of proportionality and good linkage, although in this case (and in contrast to the more common Lijphartian-inspired route of most scholars) we have placed even greater emphasis on the latter than the former. Our review of the evidence using CSES data provides firm support for the view that preferential voting can make a difference - in this instance to levels of voter satisfaction with democracy. Using an intra-party measure that identifies the main characteristics of preferential system, our comparative analysis has shown that such systems promote a greater sense of fairness about election outcomes among citizens, which in turn is a major component of the public's satisfaction with the democratic system. Electoral engineers being asked to comment on electoral 
system design for the next new democracy (or, for that matter, established democracy engaging in a major overhaul of its electoral institutions) might want to take note.

\section{Acknowledgements}

Previous versions of this article were presented at the 2003 annual meetings of the American Political Science Association (Philadelphia), the Elections, Public Opinion and Parties specialist group of the United Kingdom Political Studies Association (Cardiff) and the Australasian Political Studies Association (Hobart). We are grateful to the participants for their comments, as well as to Susan Banducci, Ben Reilly, Matthew Shugart, and our referees for helpful comments and feedback. The Comparative Study of Electoral Systems (CSES) is based at the Center for Political Studies, University of Michigan, Ann Arbor. We are grateful to the CSES for release of this data set, and to all the collaborators who made this possible. Early research for this article benefited from a Visiting Fellowship David Farrell held in 2000 at the Research School of Social Sciences at the Australian National University. The usual disclaimer applies. 


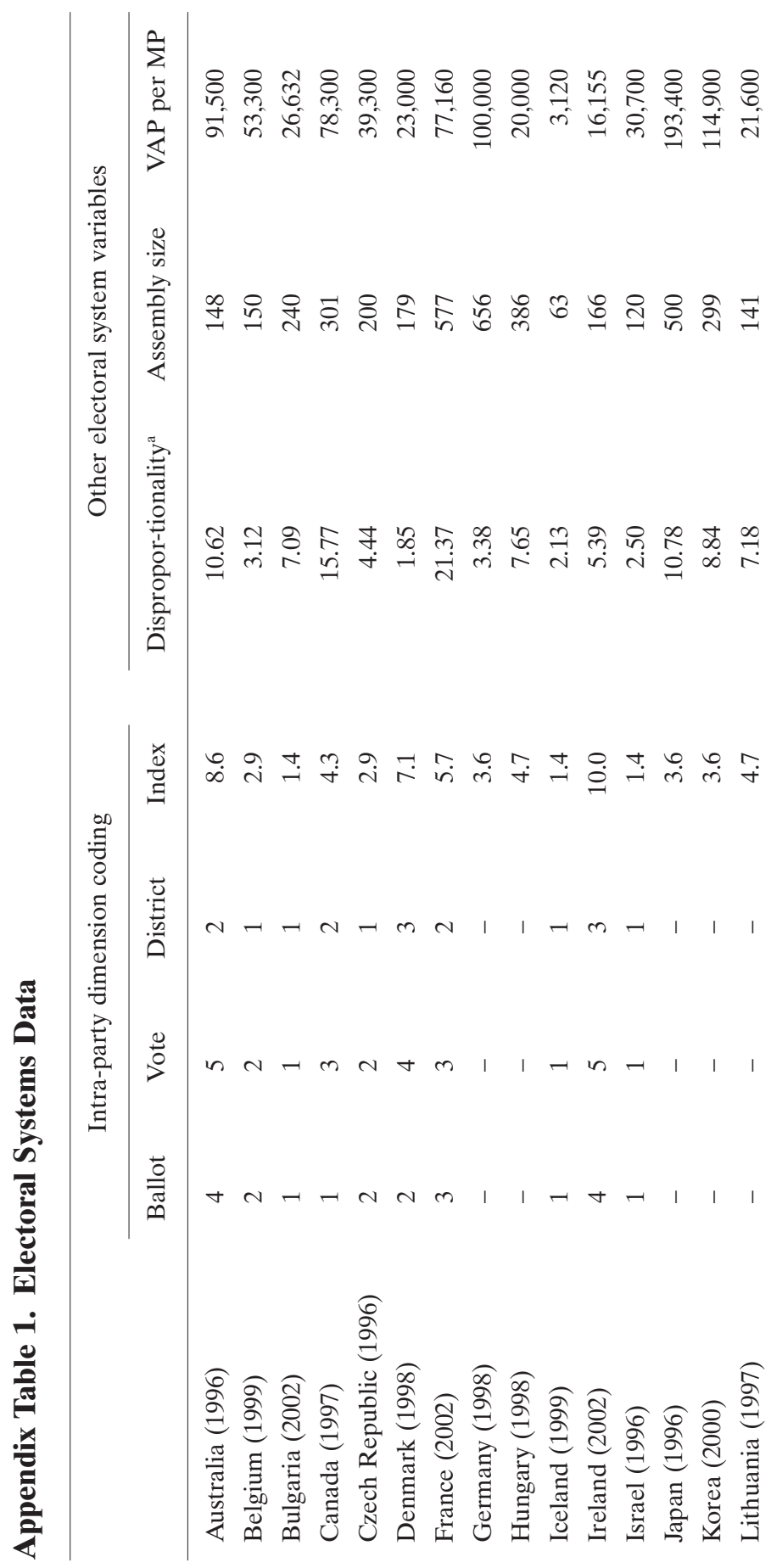




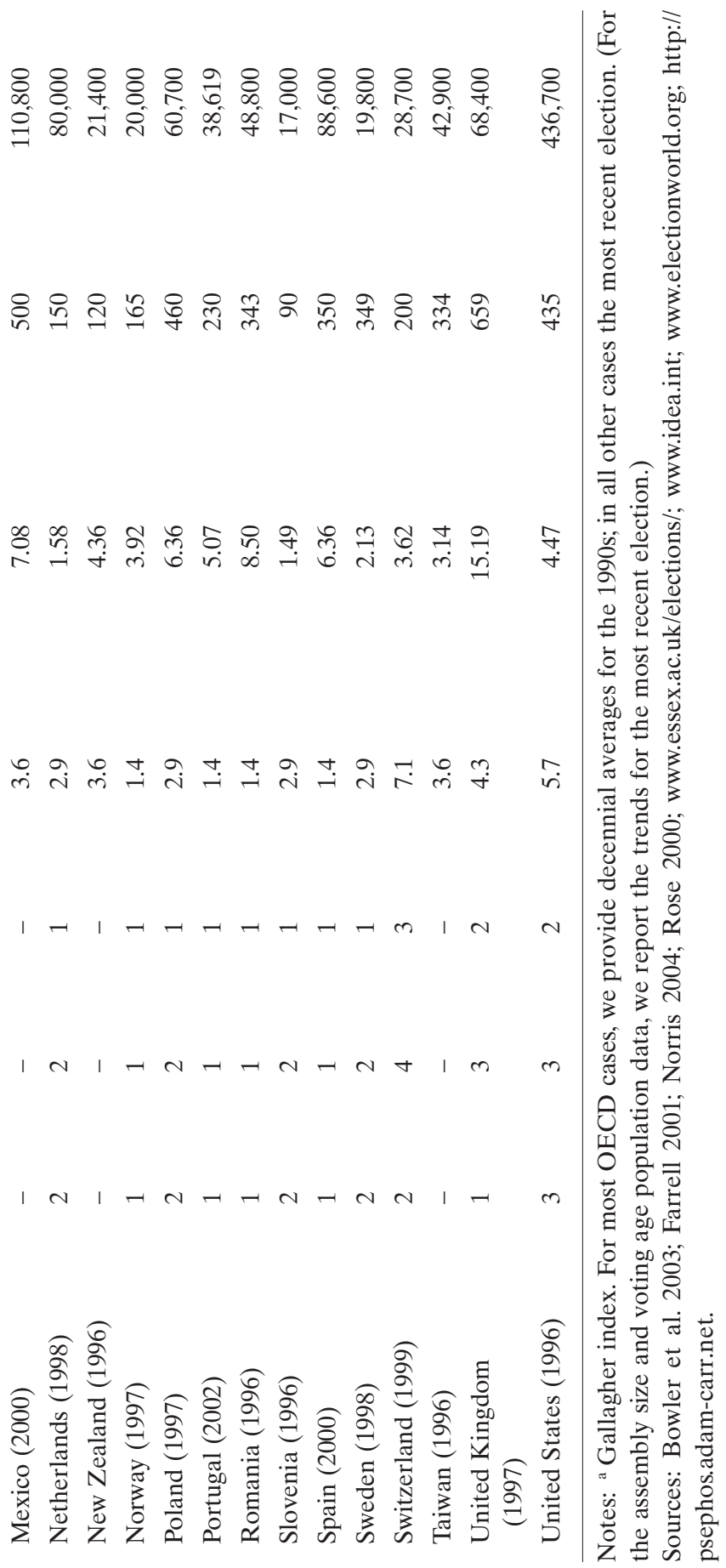




\section{Notes}

1. Unlike the few earlier efforts to examine the relationship between ballot structure characteristics and levels of democractic satisfaction (Curtice \& Shively n.d.; Norris 2004), the merits of the approach to be outlined here is that we provide a more nuanced delineation of electoral systems on this dimension, which, for instance, allows us to more accurately locate the mixed electoral systems vis-à-vis the other more established systems.

2. Since these selection rules are not readily available for all the countries in the CSES sample, our coding is more akin to that of Carey and Shugart (1995: 420-421).

3. The electoral systems referred to in parentheses after each of these bullet points are for illustrative purposes only.

4. We add the subscripts to distinguish between the Carey and Shugart (1995) codes and the Shugart (2001) codes.

5. We fully realize that the nature of STV can vary depending on where it is used (for discussion, see Farrell \& McAllister 2005: Chapter 3); in this article, for ease of exposition, our description of STV and its behavioural consequences refers to its application in Ireland.

6. It is interesting to note how for Shugart intra-party competition does feature in the case of this component even if its significance tends to be downplayed for the other components.

7. The 29 countries are listed in Appendix Table 1. Of the 29 countries, 26 were derived from module 1 of the CSES dataset (www.umich.edu/ cses/), and three (Bulgaria, France and Ireland) from module 2. Note that we are only including democratic countries in our CSES sample (based on the usual Freedom House scores). A merged data set was created from the common items of interest in the two data sets. The fieldwork dates for the surveys are shown in Appendix Table 1. Belgium was separated in module 1 between Flanders and Walloon; in our analysis the two samples are combined.

8. One country that we would have liked to include in the analyses (Thailand) did not include a question on turnout at the previous election and therefore had to be excluded. A second issue with the turnout measure in the CSES data is the over-estimation of turnout. Few of the CSES countries provide validation of voters, thereby over-estimating the actual number of voters. In reducing the error associated with this measure, we have followed the approach of Karp and Banducci (2004:11) by assuming that non-responses to the turnout question are non-voters and weighting the countries to compensate for unequal sample sizes.

9. A range of additional socio-economic variables were examined in the preliminary analyses, but eventually excluded because they added little or nothing to the explanatory power of the model.

10. $\mathrm{GI}=\sqrt{ }\left\{\left[\Sigma\left(v_{i}-s_{i}\right)^{2}\right] / 2\right\}$

11. An additional control variable would be number of elapsed years since the last election on the grounds that respondents who had voted most recently would be more satisfied than voters with more distant memories of the event. However, since the CSES data are based on national election surveys, in almost all cases the elapsed time since the last election was zero.

12. Since the sample size is large, we have noted only statistical significance at 0.01 level, and omitted standard errors and $p$ values in the interests of parsimony.

13. Another possibility is that there are country-specific variations above and beyond the variables controlled for in the fourth model that account for the differences. Several 
multilevel models were estimated to test the random and fixed country effects. However, the 29 countries were too closely correlated with the electoral system and countryspecific variables in order to follow this line of enquiry further.

14. This is consistent with previous studies that have considered indirect causal effects between electoral systems and measures of democratic satisfaction. For instance, Anderson and Guillory (1997) and Norris (1999) assess the mediating role of being losers or winners in a polity as the basis for their examination of the relationship between electoral institutions and levels of democratic satisfaction.

15. The questions were: 'Some people say that political parties are necessary to make our political system work in [country]. Others think that political parties are not needed in [country]. Using the scale on this card, (where ONE means that political parties are necessary to make our political system work, and FIVE means that political parties are not needed in [country]), where would you place yourself?' 'In some countries, people believe their elections are conducted fairly. In other countries, people believe that their elections are conducted unfairly. Thinking of the last election in [country], where would you place it on this scale of one to five where ONE means that the last election was conducted fairly and FIVE means that the last election was conducted unfairly?' 'Some people say that members of [Congress/Parliament] know what ordinary people think. Others say that members of [Congress/Parliament] don't know much about what ordinary people think. Using the scale on this card, (where ONE means that the members of [Congress/Parliament] know what ordinary people think, and FIVE means that the members of [Congress/Parliament] don't know much about what ordinary people think), where would you place yourself?

\section{References}

Ames, B. (1995). Electoral strategy under open-list proportional representation. American Journal of Political Science 39: 406-433.

Anderson, C. \& Guillory, C. (1997). Political institutions and satisfaction with democracy: A cross-national analysis of consensus and majoritarian systems. American Political Science Review 91: 66-81.

Bowler, S. (1986). Reasoning voters, voter behaviour and institutions: The decision dependence of voting behaviour. In D. Farrell et al. (eds), British elections and parties yearbook, 1996. London: Frank Cass.

Bowler, S. \& Farrell, D. (1993). Legislator shirking and voter monitoring: Impacts of European Parliament electoral systems upon legislator-voter relationships. Journal of Common Market Studies 31: 45-69.

Bowler, S. \& Grofman, B. (eds) (2000). Elections in Australia, Ireland and Malta under the single transferable vote: Reflections on an embedded institution. Ann Arbor, MI: University of Michigan Press.

Bowler, S., Carter, E. \& Farrell, D. (2003). Changing party access to elections. In B. Cain, R. Dalton \& S. Scarrow (eds), Democracy transformed? Expanding political opportunities in advanced industrial democracies. Oxford: Oxford University Press.

Bowler, S. et al. (2002). Electoral reform and minority representation: Local experiments with alternative elections. Columbus, $\mathrm{OH}$ : Ohio State University Press.

Cannache, D., Mondak, J.J. \& Seligson, M.A. (2001). Meaning and measurement in crossnational research on satisfaction with democracy. Public Opinion Quarterly 65: 506-28. 
Carey, J. \& Shugart, M. (1995). Incentives to cultivate a personal vote: A rank ordering of electoral formulas. Electoral Studies 14: 417-439.

Castles, F.G. (1994). The policy consequences of proportional representation: A sceptical commentary. Political Science 46: 161-171.

Cox, G. (1990). Centripetal and centrifugal incentives in electoral systems. American Journal of Political Science 34: 903-935.

Curtice, J. \& Shively, W.P. (n.d.). Who represents us best? One member or many? (mimeo).

Easton, D. (1965). A framework for political analysis. Englewood Cliffs, NJ: Prentice-Hall

Farrell, B. (1985). Ireland: From friends and neighbours to clients and partisans: Some dimensions of parliamentary representation under PR-STV. In V. Bogdanor (ed.), Representatives of the people? Aldershot: Gower.

Farrell, D. (2001). Electoral systems. London: Macmillan Palgrave.

Farrell, D. \& Scully, R. (2003). Electoral reform and the British MEP. Journal of Legislative Studies 9: 14-37.

Farrell, D. \& McAllister, I. (2005). Australia's electoral systems. Sydney: University of New South Wales Press.

Grofman, B. et al. (eds) (1999). Elections in Japan, Korea and Taiwan under the single non-transferable vote: The comparative study of an embedded institution. Ann Arbor, MI: University of Michigan Press.

Hallett, G. (1984). Proportional representation with the single transferable vote: A basic requirement for legislative elections. In A. Lijphart \& B. Grofman (eds), Choosing an electoral system: Issues and alternatives. Westport, CT: Praeger.

Horowitz, D. (1991). A democratic South Africa? Constitutional engineering in a divided society. Berkeley, CA: University of California Press.

Karp, J. \& Banducci, S.A. (2004). Political Efficacy and Participation in Twenty-five Democracies: How Electoral Systems Shape Political Behavior. Unpublished paper.

Karp, J., Banducci, S. \& Bowler, S. (2003). To know it is to love it? Satisfaction with democracy in the European Union. Comparative Political Studies 36: 271-292.

Katz, R. (1980). A theory of parties and electoral systems. Baltimore, MD: Johns Hopkins University Press.

Katz, R. (1997a). Representational roles. European Journal of Political Research 32: 211226.

Katz, R. (1997b). Democracy and elections. Oxford: Oxford University Press.

Lakeman, E. (1974). How democracies vote: A study of majority and proportional electoral systems (4th edn). London: Faber \& Faber.

Lawson, K. (ed.) (1980). Political parties and linkage: A comparative perspective. New Haven, CT: Yale University Press.

Lijphart, A. (1994). Electoral systems and party systems: A study of twenty-seven democracies, 1945-1990. New York: Oxford University Press.

Lijphart, A. (1999). Patterns of democracy: Government forms and performance in thirty-six countries. New Haven, CT: Yale University Press.

Linde, J. \& Ekman, J. (2003). Satisfaction with democracy: A note on a frequently used indicator in comparative politics. European Journal of Political Research 42: 391-408.

Lipset, S.M. (1966). Political man. London: Mercury Books.

Marsh, M. (2000). Candidate centered but party wrapped: Campaigning in Ireland under STV. In S. Bowler \& B. Grofman (eds), Elections in Australia, Ireland and Malta under the single transferable vote: Reflections on an embedded institution. Ann Arbor, MI: University of Michigan Press. 
McLean, I. (1991). Forms of representation and systems of voting. In D. Held (ed.), Political theory today. Cambridge: Polity Press.

Mitchell, P. (2000). Voters and their representatives: Electoral institutions and delegation in parliamentary democracies. European Journal of Political Research 37: 335-351.

Norris, P. (1999). Institutional explanations for political support. In Critical citizens: Global support for democratic governance. Oxford: Oxford University Press.

Norris, P. (2004). Electoral engineering: Voting rules and electoral behavior. Cambridge: Cambridge University Press.

Rae, D. (1967). The political consequences of electoral laws. New Haven, CT: Yale University Press.

Reilly, B. (2001). Democracy in divided societies: Electoral engineering for conflict management. Cambridge: Cambridge University Press.

Reynolds, A. (1999). Electoral systems and democratization in Southern Africa. Oxford: Oxford University Press.

Reynolds, A. (ed.) (2002). The architecture of democracy: Constitutional design, conflict management and democracy. Oxford: Oxford University Press.

Römmele, A., Farrell, D. \& Ignazi, P. (eds) (2005). Political parties and political systems: The concept of linkage revisited. Westport, CT: Greenwood/Praeger.

Rose, R. (1992). What are the economic consequences of PR? London: Electoral Reform Society.

Rose, R. (ed.) (2000). International encyclopedia of elections. London: Macmillan Palgrave.

Sartori, G. (1968). Political development and political engineering. Public Policy 17:261-298.

Sartori, G. (1976). Parties and party systems: A framework for analysis. Cambridge: Cambridge University Press.

Sartori, G. (1997). Comparative constitutional engineering: An inquiry into structures, incentives and outcomes (2nd edn). London: Macmillan.

Shugart, M. (2001). Electoral 'efficiency' and the move to mixed-member systems. Electoral Studies 20: 173-193.

Shugart, M. \& Wattenberg, M. (eds) (2001). Mixed-member electoral systems: The best of both worlds? Oxford: Oxford University Press.

Sisk, T. (1995). Democratization in South Africa: The elusive social contract. Princeton, NJ: Princeton University Press.

Taagepera, R. (2002). Designing electoral rules and waiting for an electoral system to evolve. In A. Reynolds (ed.), The architecture of democracy: Constitutional design, conflict management and democracy. Oxford: Oxford University Press.

Taagepera, R. \& Shugart, M. (1989). Seats and votes: The effects and determinants of electoral systems. New Haven, CT: Yale University Press.

Thomassen, J. \& Kolk, H. van der. (forthcoming). Economic performance and satisfaction with democracy. In H.-D. Klingemann (ed.), A comparative study of electoral systems. Oxford: Oxford University Press.

Weaver, R.K. \& Rockman, B.A. (eds) (1993). Do institutions matter? Government capabilities in the United States and abroad. Washington, DC: Brookings Institution.

Address for correspondence: David M. Farrell, School of Social Sciences, University of Manchester, Manchester M13 9PL, UK. E-mail: David.Farrell@manchester.ac.uk 